\title{
Rational use of medicines: prescribing indicators at different levels of health care
}

\author{
Maria Beatriz Cardoso Ferreira ${ }^{1, *}$, Isabela Heineck², Liziane Maahs Flores ${ }^{3}$, Aline Lins Camargo 4 , \\ Tatiane da Silva Dal Pizzol ${ }^{2}$, Iraci Lucena da Silva Torres ${ }^{1}$, Alvaro Koenig ${ }^{5}$, Daisson José Trevisol ${ }^{6}$, \\ Adriana Mary Mestriner Felipe de Melo ${ }^{7}$, Teófilo Fernando Mazon Cardoso ${ }^{8}$, Maria Tereza \\ Ferreira Duenhas Monreal ${ }^{8}$, Mônica Cristina Toffoli Kadri ${ }^{8}$
}

\begin{abstract}
${ }^{1}$ Department of Pharmacology, Basic Science of Health Institute, Federal University of Rio Grande do Sul, ${ }^{2}$ Department of Production and Control of Medicines, College of Pharmacy, Federal University of Rio Grande do Sul, ${ }^{3}$ Department of Community Health, College of Pharmacy, Federal University of Santa Maria, ${ }^{4}$ Department of Basic Science of Health, University of Health Sciences of Porto Alegre, ${ }^{5}$ Department of Medicine, Faculty of Medicine, University of Region of Joinville, ${ }^{6}$ Department of Biological and Health Sciences and of Social Applied Sciences, College of Pharmacy, University of South of Santa Catarina, ${ }^{7}$ College of Pharmacy, University of Grande Dourados, ${ }^{8}$ College of Pharmacy, Federal University of Mato Grosso do Sul
\end{abstract}

\begin{abstract}
This multicenter study aimed to investigate prescribing patterns of drugs at different levels of health care delivery in university-affiliated outpatient clinics located in eight cities in the South and Midwest of Brazil. All prescriptions collected were analyzed for various items, including WHO prescribing indicators. A total of 2,411 prescriptions were analyzed, and 469 drugs were identified. The number of drugs prescribed per encounter, the frequency of polypharmacy, and the percentage of encounters with at least one injection or antibiotic prescribed were higher in centers providing primary health care services, compared to those where this type of care is not provided. Most drugs (86.1\%) were prescribed by generic name. In centers with primary health care services, drug availability was higher, drugs included in the National and Municipal Lists of Essential Medicines were more frequently prescribed, and patients were given more instructions. However, warnings and non-pharmacological measures were less frequently recommended. This study reveals trends in drug prescribing at different levels of health care delivery in university-affiliated outpatient clinics and indicates possible areas for improvement in prescribing practices.
\end{abstract}

Keywords: Medicines/rational use. Medicines/prescription. Health Care/quality indicators. Pharmacy/ community services.

Este estudo multicêntrico teve como objetivo investigar o padrão de prescrição de medicamentos para pacientes ambulatoriais atendidos em serviços de saúde vinculados a universidades com diferentes níveis de atenção, em oito cidades do sul e centro-oeste do Brasil. As prescrições coletadas foram submetidas à análise de diversos itens, incluindo os indicadores de prescrição propostos pela OMS. No total, 2.411 prescrições foram analisadas e 469 medicamentos foram identificados. O número de medicamentos prescritos por consulta, a frequência de polifarmácia e a porcentagem de consultas com pelo menos um medicamento injetável ou um antimicrobiano prescrito foram maiores em centros de saúde que ofereciam cuidados de atenção básica, em comparação com aqueles que não dispunham desse tipo de atendimento. A maioria dos medicamentos foi prescrita pelo nome genérico $(86,1 \%)$. Em unidades com cuidados de atenção básica, a acessibilidade foi maior, a prescrição de medicamentos presentes nas Listas Nacional e Municipais de Medicamentos Essenciais foi mais frequente e instruções foram fornecidas aos pacientes mais comumente. Entretanto, advertências e medidas não farmacológicas foram indicadas com menor frequência. Este estudo revela tendências de prescrição de medicamentos em serviços de

*Correspondence: M. B. C. Ferreira. Rua Anita Garibaldi, 500/405, 90450-

000 - Porto Alegre - Rio Grande do Sul, Brazil. E-mail: mariabea@ufrgs.br 
saúde ligados a universidades, com diferentes níveis de atenção, e indica possíveis áreas de melhoria na prática da prescrição.

Unitermos: Medicamentos/uso racional. Medicamentos/prescrição. Assistência à Saúde/indicadores de qualidade. Farmácia/serviços comunitários.

\section{INTRODUCTION}

The World Health Organization (WHO) suggests a set of drug use indicators that has proven useful in the investigation of drug prescribing patterns in health care facilities (WHO, 1993). Prescribing indicators have been used in several studies, showing problems in the pattern of drug prescribing in different regions of the world (Mahfouz et al., 1997; Nikfar et al., 2005; Sharif et al., 2008; Vallano et al., 2004). These studies provide data to be used in future strategies aiming to promote rational drug use.

Prescriptions are a legal document holding the prescribing physician and the dispensing pharmacist responsible for all drugs that are prescribed and dispensed (Sharif et al, 2008). In accordance with the Brazilian health regulations (Brasil, 1973), a medication order should carry several items, such as name and address of the patient and name, address, medical license number and signature of the prescriber. The presence of these and other data aims at a more rational use of drugs, minimizing drug-related problems and improving treatment outcomes.

Several studies have assessed patterns of drug use practices in the primary health care setting using WHO prescribing indicators (Colombo et al., 2004; Mahfouz et al., 1997; Nikfar et al., 2005; Oliveira et al., 2009; Santos, Nitrini, 2004; Sharif et al., 2008; Vallano et al., 2004). However, it is also important to assess the drug use situation in health facilities that provide more complex health services. Although specific indicators have not been described for these services, WHO prescribing indicators for primary care may be a helpful tool for such work in secondary and tertiary care settings.

Institutions providing primary, secondary and tertiary care are often affiliated with universities, and a previous study suggested that prescribing routines experienced by medical students/interns in these environments are to be repeated later in the course of their professional lives (Heineck et al., 2000).

Therefore, the objective of this study was to investigate prescribing patterns at different levels of health care delivery in university-affiliated outpatient clinics located in the South and Midwest regions of Brazil.

\section{METHODS}

This cross-sectional and multicenter study was conducted at university-affiliated outpatient clinics located in eight cities in the South and Midwest of Brazil. The cities have different population sizes, as follows: less than 100,000 inhabitants (Lajeado and Tubarão), between 100,000 and 200,000 inhabitants (Passo Fundo and Dourados), between 300,000 and 500,000 inhabitants (Caxias do Sul and Joinville), and more than 500,000 inhabitants (Campo Grande and Porto Alegre).

\section{Description of research sites}

According to the national registry of health institutions of the Brazilian Ministry of Health (Brasil, 2011), all eight centers participating in this study were classified as providing secondary care services (availability of medical specialists and expert health professionals in specific areas, such as endocrinologists and cardiologists, and more advanced technological resources to support diagnosis and treatment). Six of these centers also delivered primary care services within their facilities (accounting for $81 \%$ of all prescriptions analyzed). Two centers also provided tertiary (but not primary) care and accounted for $19 \%$ of the prescriptions analyzed. The criteria for inclusion of outpatient clinics were: (1) being affiliated with the Federal University of Rio Grande do Sul (UFRGS) as a research partner, (2) being located in municipalities of different sizes, categorized according to the number of inhabitants, (3) offering internships for undergraduate and/or graduate students in the health area (including residency programs), who should have access to different prescribing patterns. A detailed description of the characteristics of the municipalities and outpatient clinics participating in this study has been published elsewhere (Dal Pizzol et al., 2010).

\section{Sampling}

Data were collected over a 12 -month period in each research site, during the years of 2006, 2007 and 2008. All prescriptions issued to adult outpatients were included. We established a minimum of 24 interviews per 
month at each research site, which resulted in a minimum sample of 288 prescriptions per municipality over 12 months. Participants were recruited by convenience sampling. Monthly data collection was performed on three randomly chosen days of the same week of the month. If the estimated number of patients was not reached (8 patients/day), an additional day was randomly chosen in the following week. If, at any time, the additional day fell on an already chosen day, lots would be drawn again until the overlap was eliminated.

\section{Data collection and analysis}

Patients were approached at the outpatient clinic or the pharmacy and invited to participate immediately after the consultation. A specific questionnaire was completed for each patient who received a prescription. The research team was previously trained to conduct the interview and collect data.

WHO prescribing indicators (WHO, 1993) were analyzed, including number of drugs per encounter (per prescription), percentage of encounters with at least one injection or antibiotic prescribed, frequency of polypharmacy (defined as encounters with five or more drugs prescribed), percentage of drugs prescribed by generic name, percentage of drugs prescribed belonging to the 14th WHO Model List (WHO, 2005), to the Brazilian National List of Essential Medicines (RENAME) (Brasil, 2002), and to the local List of Essential Medicines from each city participating in the study. The list of antibiotics included in the analysis was based on the WHO antimicrobial classification for prescribing indicators (WHO, 1993). We also analyzed the percentage of different drugs prescribed, using the Anatomical Therapeutic Chemical (ATC) classification, and the number of drugs available in the same facility of the consultation.

We evaluated the percentage of medical orders in accordance with the Brazilian health regulations. Important items of prescriptions (such as dosage form, dose, route of administration, interval between doses, and treatment duration) and provision of additional written information, including non-pharmacological measures, were also considered. We also analyzed whether patients received instructions and warnings about the use of the drugs prescribed and collected information on whom dispensed the medication. Instructions included information on how, when and for how long the drug should be used, how the product should be stored and what to do with the unused product. Warnings corresponded to the description of precautions, drug interactions, and how to recognize adverse drug reactions and what to do about them.

Data were entered into a database developed using EpiData 3.1 and analyzed using the Statistical Package for the Social Sciences (SPSS) for Windows, version 15.0. For analysis purposes, the different levels of health care delivery were divided into two groups - centers with and without primary health care services. Data were expressed as absolute frequency and percentage, mean and standard deviation (SD). Associations between patients' age groups and number of drugs prescribed or number of antibiotics prescribed per encounter were analyzed using the chisquare test with adjusted standardized residuals. The Student $t$ test was used to assess the statistical significance between means. A $P$-value $<0.05$ was considered to be statistically significant.

\section{Ethical aspects}

The study protocol was approved by the Institutional Review Boards of all centers involved in the study. Written informed consent was obtained from all participants prior to their inclusion in the study.

\section{RESULTS}

A total of 2,411 prescriptions were analyzed. Most patients were female $(70.4 \%)$, with a mean age of 50.8 years (SD, 16.5; range, 17-94 years). Of the total sample, $21 \%$ were elderly patients ( $\geq 65$ years of age) and $11.3 \%$ were illiterate. Among the elderly, 24.4\% reported being illiterate. Among those who had some level of formal education, $63.9 \%$ attended only primary school (until the eighth grade), $18 \%$ attended high school, and $6.8 \%$ attended university.

Although patients' mean age was lower in centers with primary health care services $(50.4 \pm 16.4$ vs. $52.3 \pm 17.3$ years; Student $t$ test, $P=0.038$ ), there was no statistically significant difference in the percentage of elderly patients when the levels of health care delivery were compared $(20.6 \%$ in centers with vs. $23.5 \%$ in centers without primary care; chi-square test with adjusted standardized residuals, $P=0.092$ ).

Results concerning WHO prescribing indicators (WHO, 1993) are shown in Table I. Five patients were prescribed 10 or more drugs per encounter. Two of them were prescribed 13 drugs, which was the maximum number of drugs prescribed in a consultation in this study.

The number of drugs per encounter, the frequency of polypharmacy, and the percentage of encounters with at least one injection or antibiotic prescribed were higher 
in centers with primary health care services, compared to those where this type of care is not provided (Table I).

All injections were prescribed at centers with primary health care services (Table I). The agents most commonly prescribed were insulin and insulin analogues (36.9\%), medroxyprogesterone $(9.2 \%)$, and benzathine benzylpenicillin $(7.7 \%)$, which together accounted for $53.8 \%$ of all injections prescribed.

Most antibiotics were prescribed in centers with primary health care services (Table I). Only 29 patients $(1.2 \%)$ received more than one antimicrobial agent. Fortyfive different agents were prescribed, accounting for $6.1 \%$ of all drugs prescribed. The most commonly prescribed antibiotics were amoxicillin (19.8\%), metronidazole $(10.3 \%)$, cephalexin $(7.8 \%)$, sulfamethoxazole and trimethoprim (7.8\%), and norfloxacin (6.3\%).

Comparing centers with and without primary health care services, the overall frequency of prescription of drugs by generic name and of drugs included in the WHO Model List was similar between groups. However, in centers with primary health care services, drug availability was higher $(P=0.001)$, and drugs included in the National and Municipal Lists of Essential Medicines were more frequently prescribed $(P=0.001)$ (Table I).

When analyzing the indicators of rational use of medicines according to age group, there was a significant association between the number of drugs per encounter and patient age (chi-square test with adjusted standardized residuals, $P=0.001)$. In the group aged $<65$ years, most patients were prescribed only one drug. Conversely, polypharmacy was statistically more common among elderly patients ( $15.9 \%$ vs. $6.5 \%$ in younger patients). In this study, patients aged $\geq 65$ years were prescribed a mean of 2.6 drugs (SD, 1.8; range, 1-9), which was significantly different from the value obtained for younger patients mean of 2.1 drugs (SD, 1.4; range, 1-13) (Student $t$ test, $P=0.001$ )

There was also a significant association between the percentage of antibiotics prescribed and patient age (chi-square test with adjusted standardized residuals, $P=0.001)$. Younger patients were more frequently prescribed antimicrobial agents than the elderly $(14.9 \%$ vs. $6.7 \%$ ). Twenty-seven patients aged $<65$ years were prescribed two or more antibiotics (maximum of four), while the maximum number of antibiotics received by elderly patients was two (used by two patients).

Young patients were prescribed 35 different antimicrobial agents. The most commonly prescribed antibiotics were amoxicillin $(23.6 \%)$, cephalexin $(14.6 \%)$, metronidazole $(14.2 \%)$, sulfamethoxazole and trimethoprim (9.4\%), norfloxacin (6.9\%), ampicillin $(5.2 \%)$, and azithromycin $(5.2 \%)$, accounting for $79.1 \%$

TABLE I - Indicators of rational use of medicines proposed by the World Health Organization (WHO), as assessed in outpatient clinics in eight Brazilian cities* (2006-2008), considering the different levels of health care delivery - centers with or without primary health care services

\begin{tabular}{lccc}
\hline Prescribing indicator & $\begin{array}{c}\text { Total sample } \\
(\mathrm{n}=2,411)\end{array}$ & $\begin{array}{c}\text { With primary care } \\
(\mathrm{n}=1,956)\end{array}$ & $\begin{array}{c}\text { Without primary care } \\
(\mathrm{n}=455)\end{array}$ \\
\hline Number of drugs per encounter $(\text { mean } \pm \mathrm{SD})^{\mathrm{a}}$ & $2.2 \pm 1.5$ & $2.3 \pm 1.6$ & $1.6 \pm 1.0^{\mathrm{b}}$ \\
(range) & $(1-13)$ & $(1-13)$ & $(1-7)$ \\
Encounters with only one drug prescribed & $42 \%$ & $38.2 \%$ & $58 \%^{\mathrm{c}}$ \\
Encounters with five or more drugs prescribed (polypharmacy) & $8.5 \%$ & $9.9 \%$ & $2.6 \%^{\mathrm{c}}$ \\
Encounters with at least one injection prescribed & $2.5 \%$ & $3.1 \%$ & $0 \%^{\mathrm{c}}$ \\
Encounters with at least one antibiotic prescribed & $13.1 \%$ & $15.5 \%$ & $3.1 \%^{\mathrm{c}}$ \\
Drugs prescribed by generic name & $86.1 \%$ & $86.4 \%$ & $84.4 \%$ \\
Drugs included in the WHO Model List & $62.3 \%$ & $62.1 \%$ & $63.1 \%$ \\
Drugs included in the National List of Essential Medicines & $73.7 \%$ & $81.0 \%$ & $52.6 \%^{\mathrm{c}}$ \\
Drugs included in the local List of Essential Medicines & $77.4 \%$ & $81.4 \%$ & $54.8 \%^{\mathrm{c}}$ \\
Drugs available in the same facility of the consultation & $65.9 \%$ & $68.1 \%$ & $53.7 \%^{\mathrm{c}}$ \\
\hline
\end{tabular}

$\mathrm{SD}=$ standard deviation.

${ }^{a}$ Median of 2 drugs per encounter (25th-75th percentile, 1-3) in the total sample and centers with primary health care services; median of 1 (25th-75th percentile, 1-2) in centers without primary health care services.

${ }^{\mathrm{b}}$ Statistically different from centers with primary health care services; Student $t$ test, $P=0.001$.

c Statistically different from centers with primary health care services; chi-square test with adjusted standardized residuals, $P=0.001$.

*Lajeado, Tubarão, Passo Fundo, Dourados, Caxias do Sul, Joinville, Campo Grande, and Porto Alegre. 
of all antibiotic prescriptions in these patients. Elderly patients were prescribed 13 antimicrobial agents. The most common ones were amoxicillin (25\%), cephalexin (15.6\%), norfloxacin (12.5\%), sulfamethoxazole and trimethoprim $(9.4 \%)$, and ciprofloxacin $(9.4 \%)$, accounting for $71.9 \%$ of all antibiotic prescriptions among the elderly.

Concerning the legal aspects of the prescription, information on the prescriber and patient was deficient (Table II). In 99.2\% of prescriptions, at least one item was incomplete and/or missing. This pattern was similar between centers with and without primary health care services. The address of the prescribing physician was the most commonly provided item, and was found in a significantly higher number of prescriptions in centers with primary health care services (chi-square test with adjusted standardized residuals, $P=0.001$ ).

Data on important items of prescriptions and provision of additional information are shown in Table III. The oral route was indicated in $83.2 \%$ of all cases $(83.5 \%$ in centers with and $75.3 \%$ in centers without primary health care services; chi-square test with adjusted

TABLE II - Legal aspects of the prescription - specific information on the prescribing physician and patient, as assessed in outpatient clinics in eight Brazilian cities* (2006-2008), considering the different levels of health care delivery - centers with or without primary health care services

\begin{tabular}{lccc}
\hline \multirow{2}{*}{ Information } & \multicolumn{3}{c}{ Prescriptions containing information } \\
\cline { 2 - 4 } & $\begin{array}{c}\text { Total sample }(\%) \\
(\mathrm{n}=2,411)\end{array}$ & $\begin{array}{c}\text { With primary care }(\%) \\
(\mathrm{n}=1,956)\end{array}$ & $\begin{array}{c}\text { Without primary care }(\%) \\
(\mathrm{n}=455)\end{array}$ \\
\hline Physician & & & 93.8 \\
$\quad$ Name & 94.8 & 95.0 & 98.5 \\
$\quad$ Signature & 97.6 & 97.4 & $16.3^{\mathrm{a}}$ \\
$\quad$ Address & 54.2 & 63.0 & 89.5 \\
$\quad$ License number & 91.7 & 92.2 & 97.1 \\
Patient & & & 4.0 \\
$\quad$ Name & 98.8 & 99.2 & \\
$\quad$ Address & 3.9 & 3.9 & 94.5 \\
Prescription & & & 94.5 \\
$\quad$ Date & 94.5 & 94.5 & \\
\hline
\end{tabular}

${ }^{a}$ Statistically different from centers with primary health care services; chi-square test with adjusted standardized residuals, $P=0.001$.

*Lajeado, Tubarão, Passo Fundo, Dourados, Caxias do Sul, Joinville, Campo Grande, and Porto Alegre.

TABLE III - Important items of the prescription, as assessed in outpatient clinics in eight Brazilian cities* (2006-2008), considering the different levels of health care delivery - centers with or without primary health care services

\begin{tabular}{lccc}
\hline \multirow{2}{*}{ Information } & \multicolumn{3}{c}{ Prescriptions containing information } \\
\cline { 2 - 4 } & $\begin{array}{c}\text { Total sample }(\%) \\
(\mathrm{n}=2,411)\end{array}$ & $\begin{array}{c}\text { With primary care }(\%) \\
(\mathrm{n}=1,956)\end{array}$ & $\begin{array}{c}\text { Without primary care }(\%) \\
(\mathrm{n}=455)\end{array}$ \\
\hline Dosage form & 97.6 & 97.5 & 98.4 \\
Dose & 78.0 & 76.0 & 89.1 \\
Route of administration & 92.3 & 91.4 & 97.4 \\
Interval between doses & 96.7 & 96.5 & 98.0 \\
Treatment duration & 91.6 & 91.7 & 91.5 \\
Instructions & 92.9 & 94.5 & $86.2^{\mathrm{a}}$ \\
Warnings & 6.9 & 5.2 & $14.1^{\mathrm{a}}$ \\
Non-pharmacological measures & 3.3 & 2.8 & $5.7^{\mathrm{a}}$ \\
\hline
\end{tabular}

${ }^{a}$ Statistically different from centers with primary health care services; chi-square test with adjusted standardized residuals, $P \leq 0.003$.

*Lajeado, Tubarão, Passo Fundo, Dourados, Caxias do Sul, Joinville, Campo Grande, and Porto Alegre. 
TABLE IV - Drugs most frequently prescribed in outpatient clinics in eight Brazilian cities* (2006-2008), considering the different levels of health care delivery - centers with or without primary health care services

\begin{tabular}{|c|c|c|c|}
\hline \multirow[b]{2}{*}{ Drugs (ATC) } & \multicolumn{3}{|c|}{ Percentage of drugs prescribed } \\
\hline & $\begin{array}{l}\text { Total sample } \\
(\mathrm{n}=2,411)\end{array}$ & $\begin{array}{c}\text { With primary care } \\
(\mathrm{n}=1,956)\end{array}$ & $\begin{array}{l}\text { Without primary care } \\
\qquad(\mathrm{n}=455)\end{array}$ \\
\hline Hydrochlorothiazide (C03AA03) & 6.4 & 7.3 & 1.2 \\
\hline Acetaminophen (N02BE01) & 6.1 & 6.6 & 2.9 \\
\hline Captopril (C09AA01) & 5.9 & 6.6 & 1.6 \\
\hline Aspirin (B01AC06) & 3.9 & 4.6 & 1.6 \\
\hline Amitriptyline (N06AA09) & 3.0 & 2.3 & 7.1 \\
\hline Ibuprofen (M01AE01) & 2.8 & 3.2 & 0.1 \\
\hline Propranolol (C07AA05) & 2.2 & 2.6 & 0 \\
\hline Simvastatin (C10AA01) & 2.2 & 2.3 & 1.4 \\
\hline Fluoxetine (N06AB03) & 2.2 & 1.2 & 8.8 \\
\hline Enalapril (C09AA02) & 2.2 & 2.5 & 0 \\
\hline Omeprazole (A02BC01) & 2.2 & 2.2 & 1.8 \\
\hline Metformin (A10BA02) & 2.1 & 2.4 & 0.7 \\
\hline Metamizole (Dipyrone) (N02BB02) & 2.1 & 2.3 & 0.5 \\
\hline Diosmin (C05CA03) & 1.3 & 0 & 8.8 \\
\hline Other therapeutic products $(\mathrm{V} 03 \mathrm{AX})^{\mathrm{a}}$ & 0.8 & 0 & 5.5 \\
\hline Warfarin (B01AA03) & 0.6 & 0 & 3.8 \\
\hline Carbamazepine (N03AF01) & 1.3 & 0.1 & 3.2 \\
\hline Fenoterol (R03AK03) ${ }^{\mathrm{b}}$ & 0.4 & 0 & 2.7 \\
\hline Budesonide (R03BA02) & 0.4 & 0 & 2.6 \\
\hline Biperiden (N04AA02) & 0.4 & 0 & 2.1 \\
\hline
\end{tabular}

$\mathrm{ATC}=$ Anatomical Therapeutic Chemical classification.

${ }^{\text {a }}$ Some were herbal products.

${ }^{\mathrm{b}}$ And other drugs for obstructive airway diseases.

*Lajeado, Tubarão, Passo Fundo, Dourados, Caxias do Sul, Joinville, Campo Grande, and Porto Alegre.

standardized residuals, $P \leq 0.001)$. Topical use was recommended for $3.9 \%$ of all drugs prescribed $(3.5 \%$ in centers with and $13.8 \%$ in centers without primary health care services; chi-square test with adjusted standardized residuals, $P \leq 0.001)$.

Information on the drug dosage regimen was considered complete only in $74.1 \%$ of all drugs prescribed. The lack of an item on the dosage regimen was significantly more common in prescriptions from centers with primary health care services $(68.9 \%$ vs. $99.9 \%$ in centers without primary health care services; chi-square test with adjusted standardized residuals, $P \leq 0.001$ ).

While instructions were more frequently found in prescriptions from centers with primary health care services, non-pharmacological measures (including homemade nasal saline solution, dressings, sitz bath, application of heat, eyelid hygiene using baby shampoo, use of condoms during sexual intercourse, and food suggestions) and warnings were more commonly reported on prescriptions from centers without primary health care services (chi-square test with adjusted standardized residuals, $P \leq 0.003$ ). The prescriber was the only source of information in most cases (70.1\%).

All prescriptions analyzed were handwritten, and a total of 469 different drugs were identified during our analysis. In only $0.6 \%$ of cases drugs could not be identified due to an illegible prescription or absence of the drug from the list of products registered with the Brazilian National Health Surveillance Agency (ANVISA, Brazil).

The most commonly prescribed therapeutic classes of drugs were analgesics $(9 \%)$, drugs targeting the renin-angiotensin-system (8.4\%), diuretics (8.2\%), psychoanaleptics $(6.4 \%)$, anti-inflammatory and antirheumatic drugs (5.2\%), and antithrombotic agents 
(5.2\%). Antimicrobial agents for systemic use were found in $4.3 \%$ of prescriptions.

In centers with primary health care services, the five most commonly prescribed drugs were agents for the treatment of cardiovascular disease (hydrochlorothiazide, captopril, and aspirin - as an antithrombotic agent) and for the management of pain and inflammatory conditions (acetaminophen and ibuprofen) (Table IV). All drugs were included in the 14th WHO Model List (WHO, 2005), the Brazilian National List of Essential Medicines (RENAME) (Brasil, 2002), and the Municipal List of Essential Medicines. In centers without primary health care services, the profile of the prescription varied greatly. Antidepressants, antiepileptics and antithrombotic agents - fluoxetine, amitriptyline, carbamazepine, and warfarin - were the most commonly prescribed drugs, and they were included in the local and National Lists of Essential Medicines. However, diosmin and other therapeutic agents, such as herbal products, were not considered essential medicines.

\section{DISCUSSION}

The aim of this study was to investigate the prescribing pattern of drugs used by outpatients attending university-affiliated public health clinics that provide different levels of health care. Significant differences were observed when centers with and without primary health care services were compared.

The number of drugs per encounter was higher in centers providing primary care (2.3 vs. 1.6 in centers without primary care). However, these values were close to the limit of two drugs per encounter recommended by WHO (WHO, 1993) and similar to or lower than figures reported for other countries or Brazilian cities, ranging from 1.44 to 3.6 (Colombo et al., 2004; Guyon et al., 1994; Mahfouz et al., 1997; Nikfar et al., 2005; Santos, Nitrini, 2004; Vallano et al., 2004).

The frequency of polypharmacy was also higher in centers with primary health care services. One possible explanation is that, in tertiary care, patients seek expert advice from a health professional for very specific complaints, resulting in a tailored prescription and reducing the likelihood of use of various drugs. In primary care, however, the patients are often considered as a whole resulting in a greater number of drugs prescribed.

Concomitant use of several drugs may be justified in the treatment of multiple chronic diseases (Gallagher et al., 2007; Shi et al., 2008). In this study, among the most frequently prescribed drugs, there were those used in the treatment of cardiovascular diseases, such as hypertension, with an estimated prevalence of 22.3 to $43.9 \%$ in Brazil (IV Brazilian Guidelines in Arterial Hypertension Work Groups, 2004; Gus et al., 2004), and metabolic syndrome, with a prevalence of $30 \%$ in a Brazilian study (Oliveira et al., 2006). Four of these drugs - hydrochlorothiazide, captopril, enalapril, and propranolol - represent drugs of choice in the treatment of these diseases. Similarly, low-dose aspirin is indicated for the prevention and treatment of cardiovascular disease and ischemic events, and simvastatin is recommended for the treatment of dyslipidemia (Harrington et al., 2008; Ito et al., 2012; Lansberg et al., 2012; Vandvik et al., 2012). Moreover, metformin was prescribed, a drug used to treat diabetes, with an estimated prevalence of $10.1 \%$ in Brazil (Toscano et al., 2008). Acetaminophen and ibuprofen, drugs with recognized efficacy and safety and commonly used in clinical practice, were also frequently prescribed for pain and inflammatory conditions. Other studies (Córdoba et al., 1999; Mahfouz et al., 1997; Vallano et al., 2004) have already reported similar results.

All drugs mentioned here are considered essential medicines according to the national and local lists. Therefore, our data suggest a rational use of medicines. However, we draw attention to the frequent prescription of amitriptyline and fluoxetine, used in the treatment of depression, and dipyrone, a drug banned in several countries, but legally marketed in Brazil.

Concerning the presence of injections on the prescription, there is no WHO recommendation as to a limit for this indicator in primary care, but the percentage observed $-2.5 \%$ in the total sample and $3.1 \%$ in centers with primary health care services - was similar to the rate of 3\% reported by Vallano et al. (2004). Three drugs accounted for $54 \%$ of cases using this dosage form: insulin - which is only available in the injectable form; benzylpenicillin - which, although an alternative therapy is available, should be preferably used in the injectable form to preserve the broad-spectrum agents; and medroxyprogesterone injection - which has been regarded as rational because it promotes better treatment adherence and consequently improves effectiveness. These three drugs have been part of the National List of Essential Medicines. The fact that these agents are recommended for diseases usually treated in centers providing primary health care may explain the percentage of injections prescribed at this level of health care in the present study.

The number of encounters with at least one antibiotic prescribed was higher in centers with primary care. This finding could be attributed to the fact that patients with manifestations of infectious diseases primarily seek a general practitioner and not a specialist. It is important 
to note that the most frequently prescribed antibiotics amoxicillin, metronidazole, cephalexin, sulfamethoxazole and trimethoprim, and norfloxacin - are indicated for prevalent infections treated in centers providing primary health care services, such as otitis media, sinusitis, and infections of the respiratory, genitourinary and gastrointestinal tracts.

WHO does not establish a limit for the number of encounters with at least one antibiotic prescribed in the primary care setting. The percentages observed in the centers with different levels of health care services, ranging from 3.1 to $15.5 \%$, were remarkably lower than the limit of $20 \%$ suggested by Cosendey et al. (2000), and below the rates reported in Andorra (29\%) (Vallano et al., 2004), Bangladesh (25\%) (Guyon et al., 1994), and Saudi Arabia (56.2\%) (Mahfouz et al., 1997). Differences observed among the studies are probably due to the epidemiological profile of infections in the different geographic areas. Factors such as prevalence of specific types of pathogens in the community, adequacy of infrastructure in the geographic area analyzed (e.g., water supply, sewage system, and hygiene habits), and health care accessibility may lead to different infection prevalence rates and distinct antibiotic prescribing patterns (Gavazzi et al., 2004). Guyon et al. (1994) assessed the use of medicines for six diseases commonly found in the outpatient clinics in rural Bangladesh - watery diarrhea, dysentery with blood, helminthiasis, pneumonia, acute respiratory tract infections, and scabies. Mahfouz et al. (1997) and Vallano et al. (2004) conducted studies in the Asir region (southwestern Saudi Arabia) and Andorra (a small European country), respectively, but failed to provide a description of specific diseases. In the first study, data were collected from the health information system of primary health care centers, and in the second study, prescriptions from different medical specialties (including General Practice, Pediatrics, Cardiology, Pulmonology, Gynecology, and Ophthalmology) were analyzed. The differences observed among the studies could be attributed to methodological aspects. Unlike the investigations by Guyon et al. (1994), Mahfouz et al. (1997) and Vallano et al. (2004), in this study the health centers were affiliated with universities, which may have influenced the prescribing patterns, reducing the use of antimicrobials.

Nevertheless, the low rate of antibiotic prescription in the present study does not indicate that the prescribing pattern in Brazil is better than in other countries, since we did not analyze the criteria justifying the clinical indication for the antibiotic order. However, when analyzing the most frequently prescribed agents, four of them - amoxicillin, metronidazole, cephalexin, and sulfamethoxazole and trimethoprim - were present in the local and National Lists of Essential Medicines and accounted for $45.7 \%$ of all antibiotics prescribed, suggesting a rational prescribing pattern.

In this study, young patients were more frequently prescribed antibiotics (14.9\% vs. $6.7 \%$ in the elderly), which is in agreement with the results reported by Vallano et al. (2004) (25\% for young patients vs. 16.5\% for the elderly). The impossibility of establishing a relationship between the prescription and the infectious disease diagnosed limits data analysis. However, the prevalence of specific infections in these age groups may explain the observed differences. Beta-lactam antibiotics, fluoroquinolones and the combination of sulfonamide and trimethoprim accounted for $79.1 \%$ of all antimicrobial prescriptions in the elderly, which is consistent with the most common infections reported in this age group - pneumonia, urinary tract infections, and skin and soft tissue infections (Gavazzi et al., 2004; Bellmann-Weiler, Weiss, 2009). Moreover, drugs such as ampicillin, metronidazole and azithromycin, which were prescribed for many young patients (but have other clinical indications), showed a percentage of zero prescription among the elderly (data not shown). Another possible explanation is related to differences in disease severity, since the clinical presentation of infection may be different in the elderly. Signs and symptoms may be more subtle, atypical, or absent in this age group, thus hindering or delaying diagnosis and treatment (Bellmann-Weiler, Weiss, 2009; Herring et al., 2007). Additionally, infections in elderly patients are generally more severe and associated with an increased risk of death (Bellmann-Weiler, Weiss, 2009), which may lead them to seek care in emergency departments directly, instead of ambulatory services. Studies from different countries have reported that elderly patients with infectious diseases are hospitalized more often and have a higher mortality rate than younger patients (Gavazzi et al., 2004). Finally, the higher prevalence of non-rational prescription of antibiotics for infections in patients aged $<65$ years is a factor that should also be considered, since two or more antimicrobial agents were prescribed for 27 individuals in this age group (vs. only two elderly patients). Further studies are warranted to investigate differences in the epidemiology of infections in these two age groups and specific antimicrobial prescribing patterns.

In this study, drugs included in the Municipal and National Lists of Essential Medicines were more frequently prescribed (77.4\% and $73.7 \%$, respectively) than those in the WHO Model List (62.3\%). This result 
is consistent with the idea that national and local lists are compiled considering local epidemiological data and needs related to the level of health care. It is worth noting that, based on these data, the municipalities appeared to be using the list proposed nationally or, at least, they were following the same parameters for drug selection (Dal Pizzol et al., 2010). However, higher percentages were observed in other countries $-99.3 \%$ in the Asia region, Saudi Arabia (Mahfouz et al., 1997), and 85\% in Bangladesh (Guyon et al., 1994). Thus, it is reasonable to assume that it is still possible to improve adherence to essential drugs lists by prescribers.

Interestingly, the high percentage of essential drugs prescribed was not maintained in centers providing only secondary and tertiary care, which suggests that the presence of primary health care services may influence the general prescribing pattern. Moreover, it is known that essential medicines do not meet all the care needs of the population. Thus, some drugs may be appropriately prescribed in secondary and tertiary care centers, even though they are not present in the list of essential medicines. However, this does not exclude the possibility of "non-rational prescription", which may be supported by the fact that diosmin and other therapeutic products were among the most commonly prescribed items in centers without primary health care services.

Also interesting is the finding that the lower percentage of essential medicines prescribed in secondary and tertiary care centers did not determine a lower use of the generic denomination. The percentage of drugs prescribed by generic name was similar among the centers providing different levels of health care. Although the percentage observed in the total sample $(86.1 \%)$ was higher than those reported in Bangladesh (78\%) (Guyon et al., 1994), in Saudi Arabia (2.9\%) (Mahfouz et al., 1997), and in Andorra (6\%) (Vallano et al., 2004), WHO suggests prescribing $100 \%$ of drugs by generic name in the primary health setting. Likewise, the Brazilian health regulations require the use of the generic denomination while prescribing in the Public Health System (Brasil, 2001). One possible explanation for these discrepancies is the prescription of drugs that are not listed on the essential medicines lists, which could lead to the use of brand names. Another possibility is the lack of knowledge about the essential medicines lists and current legislation. Marketing strategies in the pharmaceutical industry, emphasizing the brand name of products, may also contribute to this finding. However, regardless of the level of health care delivery, prescribing drugs by generic name may reduce duplicity, improve access to medicines and, consequently, increase patient compliance with drug therapy and disease control. This practice may be improved by emphasizing to medical students the importance of properly prescribing drugs by their generic names.

In the present study, several prescribed drugs $(34.1 \%)$ were not available in the same facility of the consultation, and this percentage increased to $46.3 \%$ in centers without primary health care services. Although drug availability is not a prescribing indicator, access to medicines is an indicator of rational use of drugs and is a key priority (WHO, 2008). From the consumer's point of view, access to medicines means that drugs can be obtained within reasonable travel distance from the health facility (Nikfar et al., 2005). Lack of knowledge or prescribers' non-adherence to the List of Essential Medicines available in the municipality may contribute to this finding. Moreover, these data may indicate that local essential medicines lists are not properly considering the therapeutic needs of the health centers. Also, drug shortage may influence the choice of the prescriber for "non-essential medicines". Other aspects related to the municipal pharmaceutical care, such as presence of a pharmacy within the health center, may also affect the success of a program of essential medicines. Aiming to increase adherence to local Essential Medicines Lists, it is important that the selected drugs are periodically updated by a multidisciplinary committee, that the list is appropriately disclosed to prescribers, and that a regular supply of medicines is maintained in the pharmacy (Dal Pizzol et al., 2010).

Most patients (93\%) received written instructions for the use of prescribed medicines, but only a few received warnings and information on non-pharmacological measures ( $7 \%$ and $3 \%$, respectively). The prescription is the main source of information about the pharmacological treatment and, according to WHO, medical orders should contain, at least, the following items: drug effects, warnings, instructions for use, and adverse drug reactions (Organización Mundial de la Salud, 1998). Several health professionals provide only verbal information, which may not be effective, because patients tend to forget approximately half of the information received (Ley, 1982).

Overall, data resulting from the analysis of prescribing indicators in this study suggest a rational use of medicines. This may be attributed to the facilities where the data were collected - university-affiliated health centers. This is a very important feature as these places are well recognized by their role in the education of future health professionals. Heineck et al. (2000) showed that Brazilian prescribers appointed learning during internship and health care routines as the main sources of knowledge about drug 
prescription. Conversely, the results clearly demonstrated the need for considerable improvement in prescribing practices even in these university-affiliated centers.

A limitation of the study is that drug prescribing patterns were assessed in health centers within a university setting, and the data cannot be extrapolated to centers without this characteristic context.

We concluded that drug prescribing practices should be improved regardless of the level of health care delivery. It is necessary to implement institutional guidelines in order to achieve more appropriate prescribing patterns, to promote prescription based on the list of essential medicines, and to highlight the importance of these practices in medical school and continuing medical education for a more rational and safer use of medicines.

\section{ACKNOWLEDGMENTS}

We are greatly indebted to Adriana Rodrigues Machado, Mariana da Silva Formigheri, Clarissa Finger Rodrigues, Luciana Carvalho Fernandes, Renan Candemil, Larissa Martins Schmitz, Eduardo Savi, Juliana Zatti, Janine Boniatti, Natália D'Agostini, Gabriela Fachinelli, Vanelise Zortéa and Camila Segat for their assistance in data collection.

\section{FINANCIAL SUPPORT}

Conselho Nacional de Desenvolvimento Científico e Tecnológico (CNPq) (Edital MCT/CNPq/MS-SCTIEDECIT-DAF 54/2005 - Assistência Farmacêutica).

\section{CONFLICT OF INTEREST}

The authors declare that they have no conflict of interest.

\section{REFERENCES}

BELLMANN-WEILER, R.; WEISS, G. Pitfalls in the diagnosis and therapy of infections in elderly patients: a mini-review. Gerontology, v.55, n.3, p.241-249, 2009.

BRASIL. Lei Federal n.5991, de 17 dez. 1973. Dispõe sobre o Controle Sanitário do Comércio de Drogas, Medicamentos, Insumos Farmacêuticos e Correlatos, e dá outras Providências. Diário Oficial da União, Brasília, 19 dez. 1973. Seção 1. p.13.049. Available at: <http://e-legis. anvisa.gov.br/leisref/public/search.php>. Accessed on: 29 Sept. 2011.
BRASIL. Ministério da Saúde. Secretaria de Políticas de Saúde. Departamento de atenção básica. Gerência técnica de assistência farmacêutica. Relação nacional de medicamentos essenciais - RENAME. 3ed. Brasília: Ministério da Saúde, 2002. Série B. Textos Básicos de Saúde. Available at: <http://bvsms.saude.gov.br/bvs/ publicacoes/relacao_nac_med_essenciais.pdf $>$. Accessed on: 12 March 2013.

BRASIL. Ministério da Saúde. Agência Nacional de Vigilância Sanitária. Resolução RDC n.10 de 2 jan. 2001. Available at: <http://www.anvisa.gov.br/legis/resol/10_01 rdc.htm>. Accessed on: 29 Sept. 2011.

BRASIL. Ministério da Saúde. Cadastro nacional de estabelecimentos de saúde. Brasília: Ministério da Saúde, 2011. Available at: $<$ http://cnes.datasus.gov.br $>$. Accessed on: 25 Sept. 2011.

IV Brazilian guidelines in arterial hypertension work groups. Arq. Bras. Cardiol., v.82, supl.4, p.7-22, 2004.

COLOMBO, D.; HELENA, E.T.S.; AGOSTINHO, A.C.M.G.; DIDJURGEIT, J.S.M.A. Padrão de prescrição de medicamentos nas unidades de Programa de Saúde da Família de Blumenau. Braz. J. Pharm. Sci., v.40, n.4, p.549-558, 2004.

CÓRDOBA, J.P.D.; GARCÍA, F.D.; LORENZO, I.A.S.; ROCHE, R.G.G.; GORBEA, M.H.B.; LARREA, N.F. Estado de la prescripción de medicamentos en la atención primaria de salud de ciudad de La Habana, 1997. Rev. Cubana Med. Gen. Integr., v.15, n.2, p.140-150, 1999.

COSENDEY, M.A.E.; BERMUDEZ, J.A.Z.; REIS, A.L.A.; SILVA, H.F.; OLIVEIRA, M.A.; LUIZA, V.L.; Assistência farmacêutica na atenção básica de saúde: a experiência de três estados brasileiros. Cad. Saúde Pública, v.16, n.1, p.171-182, 2000.

DAL PIZZOL, T.S.; TREVISOL, D.J.; HEINECK, I.; FLORES, L.M.; CAMARGO, A.L.; KOENIG, A.; TORRES, I.L.S.; KADRI, M.C.T.; MONREAL, M.T.F.D.; MELO, A.M.M.F.; FERREIRA, M.B.C. Adesão a listas de medicamentos essenciais em municípios de três estados brasileiros. Cad. Saúde Pública, v.26, n.4, p.827-836, 2010.

GALLAGHER, P.; BARRY, P.; O'MAHONY, D. Inappropriate prescribing in the elderly. J. Clin. Pharm. Ther, v.32, n.2, p.113-121, 2007. 
GAVAZZI, G.; HERRMANN, F.; KRAUSE, K-H. Aging and infectious diseases in the developing world. Clin. Infect. Dis., v.39, p.83-91, 2004.

GUS, I.; HARZHEIM, E.; ZASLAVSKY, C.; MEDINA, C.; GUS, M. Prevalence, awareness, and control of Systemic Arterial Hypertension in the State of Rio Grande do Sul. Arq. Bras. Cardiol., v.83, n.5, p.429-433, 2004.

GUYON, A.B.; BARMAN, A.; AHMED, J.U.; AHMED, A.U.; ALAM, M.S. A baseline survey on use of drugs at the primary health care level in Bangladesh. Bull. World Health Organ., v.72, n.2, p.265-271, 1994.

HARRINGTON, R.A.; BECKER, R.C.; CANNON, C.P.; GUTTERMAN, D.; LINCOFF, A.M.; POPMA, J.J.; STEG, G.; GUYATT, G.H.; GOODMAN, S.G. Antithrombotic therapy for non-ST-segment elevation acute coronary syndromes. Chest, v.133, suppl.6, p.670S-707S, 2008.

HEINECK, I.; FERREIRA, M.B.C.; SCHENKEL, E.P. Antibioticoprofilaxis quirúrgica: práctica de prescripción y nivel de conocimiento. Acta Farm. Bonaerense, v.19, n.4, p.295-302, 2000.

HERRING, A.R.; WILliAMSON, J.C. Principles of antimicrobial use in older adults. Clin. Geriatr. Med., v.23, p.481-497, 2007.

ITO, M.K. Dyslipidemia: management using optimal lipidlowering therapy. Ann. Pharmacother, v.46, n.10, p.1.368$1.381,2012$.

LANSBERG, M.G.; O’DONNELL, M.J.; KHATRI, P.; LANG, E.S.; NGUYEN-HUYNH, M.N.; SCHWARTZ, N.E.; SONNENBERG, F.A.; SCHULMAN, S.; VANDVIK, P.O.; SPENCER, F.A.; ALONSO-COELLO, P.; GUYATT, G.H.; AKL, E.A. Antithrombotic and thrombolytic therapy for ischemic stroke: antithrombotic therapy and prevention of thrombosis. Chest, v.141, suppl.2, p.601S-636S, 2012.

LEY, P. Satisfaction, compliance and communication. Br. J. Clin. Psychol., rev.21, pt.4, p.241-254, 1982.

MAHFOUZ, A.A.; SHEHATA, A.I.; MANDIL, A.M.; ALERIAN, R.A.; AL-KHUZAYEM, A.A.; KISHA, A. Prescribing patterns at primary health care level in the Asir Region, Saudi Arabia: an epidemiologic study. Pharmacoepidemiol. Drug Saf., v.6, n.3, p.197-201, 1997.
NIKFAR, S.; KEBRIAEEZADEH, A.; MAJDZADEH, R.; ABDOLLAHI, M. Monitoring of National Drug Policy (NDP) and its standardized indicators; conformity to decisions of the national drug selecting committee in Iran. BMC Int. Health Human Rights, v.5, n.5, p.5, 2005.

OLIVEIRA, E.P.; SOUZA, M.L.A.; LIMA, M.D.A. Prevalência de síndrome metabólica em uma área rural do semi-árido baiano. Arq. Bras. Endocrinol. Metab., v.50, n.3, p.456465, 2006.

OLIVEIRA, C.A.P.; MARIN, M.J.S.; MARCHIOLI, M.; PIZOLETTO, B.H.M.; SANTOS, R.V. Caracterização dos medicamentos prescritos aos idosos na Estratégia Saúde da Família. Cad. Saúde Pública, v.25, n.5, p.1.007-1.016, 2009.

ORGANIZACIÓN MUNDIAL DE LA SALUD. Guía de la buena prescripción: manual práctico. Genebra: Organización Mundial de la Salud, 1998. 108 p.

SANTOS, V.; NITRINI, S.M.O.O. Prescription and patient-care indicators in healthcare services. Rev. Saude Publ., v.38, n.6, p.819-826, 2004.

SHARIF, S.I.; AL-SHAQRA, M.; HAJJAR, H.; SHAMOUT, A.; WESS, L. Patterns of drug prescribing in a hospital in Dubai, United Arab Emirates. Libyan J. Med., v.3, n.1, p.10-12, 2008.

SHI, S.; MÖRIKE, K.; KLOTZ, U. The clinical implications of ageing for rational drug therapy. Eur. J. Clin. Pharmacol., v.64, n.2, p.183-199, 2008.

TOSCANO, C.M.; DUNCAN, B.B.; MENGUE, S.S.; POLANCZYK, C.A.; NUCCI, L.B.; COSTA, E.; FORTI, A.; FONSECA, C.D.; SCHMIDT, M.I. Initial impact and cost of a nationwide population screening campaign for diabetes in Brazil: a follow up study. BMC Health Serv. Res., v.8, p.189, 2008.

VALLANO, A.; MONTANÉ, E.; ARNAU, J.M.; VIDAL, X.; PALLARÉS, C.; COLL, M.; LAPORTE, J.R. Medical specialty and pattern of medicines prescription. Eur. J. Clin. Pharmacol., v.60, n.10, p.725-730, 2004. 
VANDVIK, P.O.; LINCOFF, A.M.; GORE, J.M.; GUTTERMAN, D.D.; SONNENBERG, F.A.; ALONSOCOELLO, P.; AKL, E.A.; LANSBERG, M.G.; GUYATT, G.H.; SPENCER, F.A. Primary and secondary prevention of cardiovascular disease: antithrombotic therapy and prevention of thrombosis. Chest, v.141, suppl.2, p.637S668S, 2012.

WORLD HEALTH ORGANIZATION. How to investigate drug use in health facilities: selected drug use indicators. Geneva: WHO, 1993. EDM Research Series n.7 [WHO/DAP/93.1].
WORLD HEALTH ORGANIZATION. Essential medicines. $14^{\text {th }}$ WHO model list. Geneva: WHO, 2005. 24p.

WORLD HEALTH ORGANIZATION. Medicines strategy 2008-2013 (draft). Geneva: WHO, 2008. 24 p. Available at: <http://www.who.int/medicines/publications/ WHOMedicinesStrategydraft.pdf.>. Accessed on: 25 Sept. 2011.

Received for publication on $10^{\text {th }}$ April 2012 Accepted for publication on $30^{\text {th }}$ January 2013 